\title{
Detection of buffaloes (Bubalus bubalis) seroreactive for vesicular stomatitis virus in the state of Paraíba, Northeastern Brazil
}

\section{Detecção de búfalos (Bubalus bubalis) sororeativos para o vírus da estomatite vesicular no Estado da Paraíba, Nordeste do Brasil}

\author{
Camila de Sousa Bezerra ${ }^{1}$; Jéssica Tatiane Sauthier ${ }^{2}$; Juliana Felipetto Cargnelutti; \\ Gisele Cândida Ramalho'; Denise Batista Nogueira ${ }^{1}$; Eduardo Furtado Flores ${ }^{3}$; \\ Rudi Weiblen ${ }^{3}$; Arthur Willian de Lima Brasi1 ${ }^{4}$; Carolina de Sousa Américo Batista \\ Santos ${ }^{5}$; Sérgio Santos Azevedo ${ }^{5 *}$
}

\begin{abstract}
This study aimed to determine the prevalence of vesicular stomatitis virus (VSV) in buffaloes in the state of Paraíba, Northeastern Brazil. The study was carried out in 14 herds in the municipalities of Alagoa Nova, Areia, Campina Grande, Guarabira, Juripiranga, Santa Helena, Sapê, Rio Tinto, Santana dos Garrotes, Itatuba, Solânea, and Cacimbas. The studied population was formed by buffalo females reared for meat and milk, comprising of mixed and Murrah breeds, at least 24 months of age. For the serological diagnosis of VSIV-3, the virus-neutralization test (VN) was performed, using the VSIV-3 isolate 2013 São Bento/Paraíba. Real prevalence was $2.6 \%$ for VSIV-3, with antibody titers ranging from 160 to 1280 . This is the first study to characterize VSV circulation in the buffalo population in Northeastern Brazil, where infection is considered endemic; some aspects of virus maintenance are not fully understood, such as the role of reservoirs in endemic areas. The identification of seroreactive animals in this study demonstrates the circulation of VSIV-3 in the buffalo species. Reports of virus isolation in this species have not yet been described, which suggests the need for investigating the role of buffaloes in vesicular stomatitis epidemiology.
\end{abstract}

Key words: VSV. VSIV-3. Vesicular stomatitis. Buffaloes. Northeastern Brazil. Prevalence. Serology.

\section{Resumo}

Este estudo teve como objetivo determinar a prevalência do vírus da estomatite vesicular (VSV) em bubalinos no estado da Paraíba, Nordeste do Brasil. O estudo foi realizado em 14 rebanhos de criação de búfalos nos municípios de Alagoa Nova, Areia, Campina Grande, Guarabira, Juripiranga, Santa Helena, Sapê, Rio Tinto, Santana dos Garrotes, Itatuba, Solânea e Cacimbas. A população estudada foi formada por fêmeas bubalinas com aptidão para carne e leite, raça mestiça e da raça Murrah, com idade $\geq 24$ meses.

1 Discentes do Curso de Mestrado, Pós-Graduação em Ciência e Saúde Animal, Universidade Federal de Campina Grande, UFCG, Campus Patos, PB, Brasil. E-mail: camila_cstr.mv@hotmail.com; giselle.spaz@gmail.com; denise.bn.medvet@gmail.com

2 Discente do Curso de Mestrado, Pós-Graduação em Biologia Celular e Molecular, UFRGS, Campus Porto Alegre, RS, Brasil. E-mail: jehsauthier@gmail.com

3 Profs. Drs., Universidade Federal de Santa Maria, UFSM, Campus Santa Maria, RS, Brasil. E-mail: jucargnelutti@gmail.com; eduardofurtadoflores@gmail.com; rudiweiblen@gmail.com

4 Prof. Dr., Universidade Federal de Rondônia, UNIR, Campus Rolim de Moura, RO, Brasil. E-mail: arthurwillian7@yahoo.com.br

5 Profs. Drs., Universidade Federal de Campina Grande, UFCG, Campus Patos, PB, Brasil. E-mail: carolamerico@yahoo.com.br; sergio@vps.fmvz.usp.br

* Author for correspondence

Received: Apr. 17, 2019 - Approved: Aug. 14, 2019 
Para o diagnóstico sorológico do VSIV-3, foi utilizado o teste de neutralização viral (VN), utilizando o isolado VSIV-3 2013 São Bento / Paraíba. Dos 119 animais testados, três (2.7\%) foram positivos para o VSIV-3, com títulos variando de 160 a 1280. Este é o primeiro trabalho de caracterização da circulação do VSV na população bubalina na Região Nordeste do Brasil, onde a infecção é considerada endêmica, no entanto, alguns aspectos da manutenção do vírus não estão totalmente esclarecidos, como o papel dos reservatórios em áreas endêmicas. A identificação de animais soropositivos nesse estudo demonstra a circulação do VSIV-3 na espécie bubalina, no entanto relatos de isolamento do agente nessa espécie ainda não foram descritos. São necessários estudos a fim de investigar qual o papel da espécie bubalina na epidemiologia da VS.

Palavras-chave: VSV. VSIV-3. Estomatite vesicular. Búfalos. Nordeste do Brasil. Prevalência. Sorologia.

Vesicular stomatitis (VS) affects cattle, swine, and horses, as well as other mammals, including humans (RODRIGUEZ, 2002). The infection is characterized by the development of vesicular lesions in the mouth, tongue, roofs, and coronary bands, with a clinical course ranging from two to three weeks. The etiological agent of VS, vesicular stomatitis virus (VSV), belongs to the order Mononegavirales, family Rhabdoviridae, genus Vesiculovirus. Among the 16 species of Vesiculovirus identified, the most prevalent are New Jersey vesiculovirus (VSNJV) and Indiana vesiculovirus (VSIV-1), both considered exotic in Brazil, Cocal vesiculovirus (VSIV-2), and Alagoas vesiculovirus (VSIV-3) (FAUQUET et al., 2005; STEFANO; PITUCO, 2016; ICTV, 2019).

VS is endemic in northern South America, and outbreaks in Brazil are mainly related to VSIV3 (PAN AMERICAN FOOT-AND-MOUTH DISEASE CENTER - PANAFTOSA, 2010), but in some regions, cases of the disease were associated with VSIV-2 (ALONSO FERNÁNDEZ; SONDAHL, 1985; PAUSZEK et al., 2011). The first isolation of VSV in Brazil was performed in 1964 (ANDRADE et al., 1980) from the oral epithelium of diseased horses in the state of Alagoas classified as VSIV-3. Two years later, VSIV-2 was identified for the first time in Brazil in horses in the state of São Paulo. According to data from the Ministry of Agriculture, Livestock and Supply (MAPA), 169 VS outbreaks, caused mainly by VSIV-3 and sporadically by VSIV-2, were reported in several states (Bahia, Ceará, Goiás, Pernambuco,
Maranhão, Mato Grosso, Minas Gerais, Pará, Paraíba, Piauí, Rio Grande do Norte, Rio de Janeiro, São Paulo, and Tocantins) between 2005 and 2013 (STEFANO; PITUCO, 2016).

Serological surveys were conducted in some Brazilian states showing VSV circulation from cattle and horses. Kotait (1990) conducted a survey of antibodies against VSIV-3 in 2,181 bovine serum samples from Vale do Paraíba, state of São Paulo, and found 36 (1.64\%) animals with positive serology. In the same state, Stefano et al. (2003) analyzed 1,099 bovine serum samples from the region of Araçatuba, state of São Paulo, and found 28 $(2.6 \%)$ seroreactive animals for VSIV-1. Outbreaks associated with VSV have also been described in Brazil. Clementino et al. (2014) reported the first outbreak of VS in the state of Paraíba, in which $43 / 82$ cattle $(52.44 \%)$ presented with clinical signs suggestive of VS, identified as VSIV-3. Cargnelutti et al. (2014) reported an outbreak of the disease in 14 horses and 6 cattle in the states of Paraíba and Rio Grande do Norte, with isolation of a virus related to VSIV-3.

In Northeastern Brazil, VSIV-3 infection is considered endemic (PANAFTOSA, 2010). Lunkes et al. (2016) investigated the presence of VSIV-3 antibodies in horses from the South, Central West, and Northeast regions, with higher seropositivity in the Northeast region $(87.3 \%$ in Ceará, $65.7 \%$ in Rio Grande do Norte, and $45.4 \%$ in Paraíba, respectively). In a study carried out in the state of Paraíba, using a planned sampling of animals and properties in the bovine population, $38.5 \%$ of the 
herds were seropositive for VSIV-3, and of these $80.6 \%$ belonged to the Sertão mesoregion, in which two spatial agglomerates of positive properties were identified (BEZERRA et al., 2018). To date there are no reports of VSIV-3 circulation in the buffalo population in Northeastern Brazil. Lunkes et al. (2016) investigated the presence of neutralizing antibodies against VSIV-3 in 758 buffaloes in the states of Rio Grande do Sul, Rondônia, and Minas Gerais, and of these, $2.6 \%$ were seroreactive, with titers varying from 40 to 1280 .

Due to the clinical similarity with foot-andmouth disease (FMD), there is a restriction on the trade and transit of animals in areas with suspected VS until confirmation of the definitive laboratory diagnosis, which is usually made by enzyme-linked immunosorbent assay (ELISA) and polymerase chain reaction (PCR) (STEFANO et al., 2003; ARRUDA et al., 2015; STEFANO; PITUCO, 2016). Considering the absence of studies on the epidemiology of VSV infection in buffaloes, and their susceptibility to both infections, it is important to characterize the areas of occurrence, given the history of viral circulation in the region. Thus, the objective of the present study was to identify the prevalence of seropositive animals for VSIV-3 in buffaloes in the state of Paraíba.

The study was conducted in 14 buffalo herds in the municipalities of Alagoa Nova, Areia, Campina Grande, Guarabira, Juripiranga, Santa Helena, Sapê, Rio Tinto, Santana dos Garrotes, Itatuba, Solânea, and Cacimbas (Figure 1). The studied population consisted of buffalo females with aptitude for meat and milk, mixed and Murrah breed, at least 24 months of age. For the calculation of the number of animals to be sampled, the formula for simple random sampling was used:

$$
n=\frac{Z^{2} \times P(1-P)}{d^{2}}
$$

$\mathrm{n}=$ number of animals to be sampled

$\mathrm{Z}=$ value of the normal distribution to the confidence level of $95 \%$

$\mathrm{P}=$ expected prevalence of $50 \%$ (for maximizing the sample)

$d=$ error of $10 \%$

Figure 1. Geographical distribution of the municipalities in which the study was carried out, in the State of Paraíba, Northeast Brazil. The dark outline shows the state of Paraíba within Brazil.

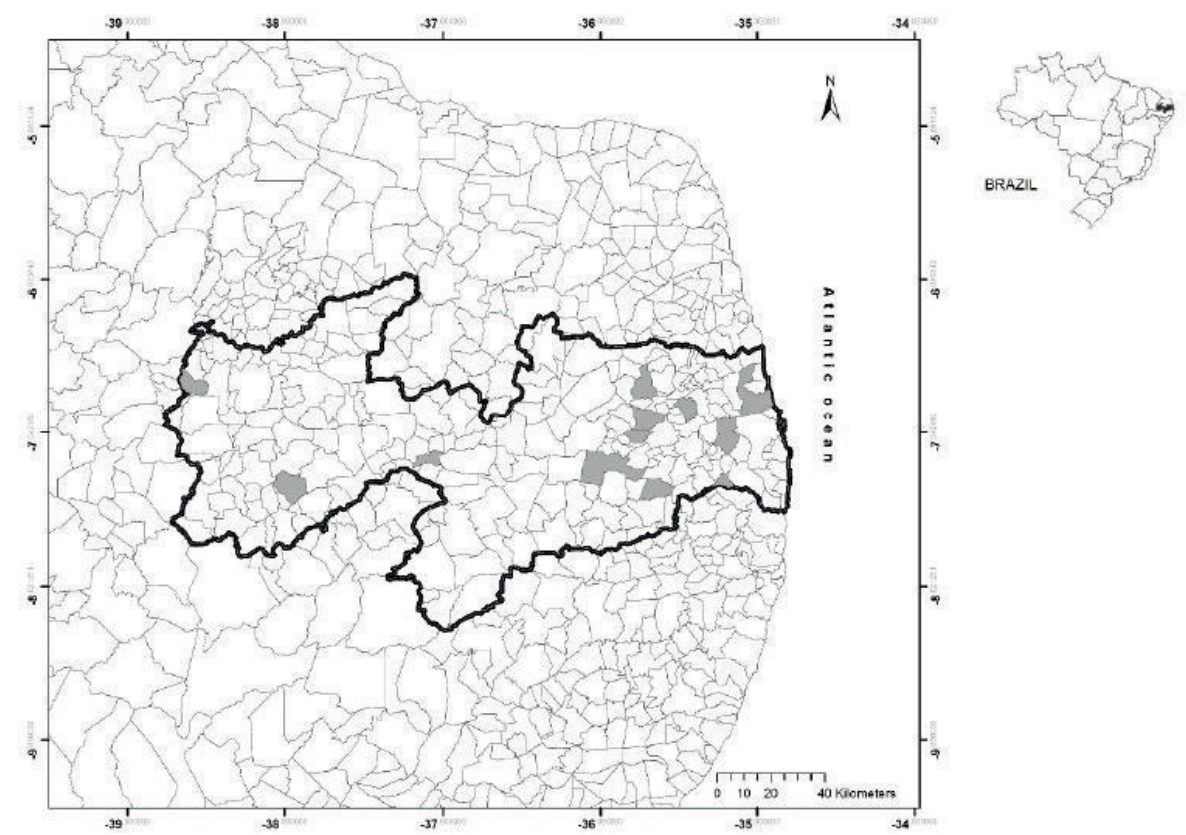


In total, 119 female buffaloes at least 24 months of age were selected from 14 herds. Blood samples were collected from November 2012 to July 2013, by venous puncture of the jugular with a disposable needle and a vacuum tube (without anticoagulant) with a capacity of $15 \mathrm{~mL}$.

Serum samples were submitted for virus neutralization (VN) testing for detection of antibodies to VSV, according to the World Organisation for Animal Health (OIE, 2015) protocol, using the isolate VSIV-3 2013 SaoBento/ ParaibaE (CARGNELUTTI et al., 2014). After complement inactivation, serum samples were diluted 1:40 and incubated with 400-500 TCID50 of the isolate VSIV-3 2013 SaoBento/ParaibaE for $1 \mathrm{~h}$ at $37^{\circ} \mathrm{C}$, followed by addition of a suspension of Vero cells and incubation at $37^{\circ} \mathrm{C}$ with $5 \% \mathrm{CO}_{2}$. The cultures were monitored for cytopathic effect (CPE) for $72 \mathrm{~h}$. Samples not presenting positive cytopathic effect were considered positive for antibodies to VSIV-3 at the used dilution. Next, positive samples were submitted to a quantitative $\mathrm{VN}$ test, in which a fixed dose of virus (400-500 TCID50) was incubated with serial two-fold dilutions of sera, starting at 1:40. After $72 \mathrm{~h}$, the cell cultures were monitored for CPE, and the VN titers were considered as the reciprocal of the highest serum dilution capable of preventing CPE.

Apparent and real prevalences were calculated according to Noordhuizen et al. (1997). Apparent prevalence was obtained by the ratio between the number of seroreactive animals and the total number of animals. Real prevalence value was estimated by the adjustment of apparent prevalence for the sensitivity (98\%) and specificity (100\%) of the VN test (ALLENDE; GERMANO, 1993; KATZ et al., 1997):

$$
R P=\frac{(A P+S P E-1)}{(S E N+S P E-1)}
$$

Where,

$\mathrm{RT}=$ real prevalence

$$
\begin{aligned}
& \mathrm{AP}=\text { apparent prevalence } \\
& \mathrm{SPE}=\text { specificity } \\
& \mathrm{SEN}=\text { sensitivity }
\end{aligned}
$$

Of the 119 animals tested, three were seroreactive for VSIV-3, with titers ranging from 160 to 1280 , resulting in an apparent prevalence of $2.5 \%$. Real prevalence was $2.6 \%$, which is similar to the value $(2.6 \% ; 20 / 758)$ observed by Lunkes et al. (2016) for VSIV-3, with titers varying from 40 to 1280 in the states of Rio Grande do Sul, Minas Gerais, and Rondônia, Brazil. According to Lunkes et al. (2016), moderate titers (160-1280) do not verify the occurrence of a recent exposure to VSIV-3; however, the presence of seroreactive animals is due to natural exposure to the virus, since there is no commercial vaccine against VSIV-3 available in Brazil.

All seroreactive animals in this study came from the same herd, located in the municipality of Santa Helena, mesoregion of Sertão paraibano (currently the Sousa-Cajazeiras intermediate region). These results corroborate with data from the epidemiological characterization of VSIV-3 in cattle in the state of Paraíba (BEZERRA et al., 2018), where $38.5 \%$ of the herds sampled in the state were seropositive to VSIV-3, and the herdlevel and animal-level prevalence in Sertão were $80.6 \%$ and $48.2 \%$, respectively. In addition, two spatial clusters of positive herds were identified in this region. Sertão is a border area of the states of Ceará, Rio Grande do Norte, and Pernambuco, where there is an intense trade of animals without the knowledge of sanitary conditions. It is worth mentioning that serological surveys for VS in horses were conducted in these states, demonstrating the presence of seropositive animals (LUNKES et al., 2016).

The circulation of VSV in the state of Paraíba was also verified from the description of outbreaks. Clementino et al. (2014) reported the first outbreak 
of VS in the state of Paraíba, and found 82 cattle (52.44\%) presenting clinical signs suggestive of infection, with VSIV-3 identification. Cargnelutti et al. (2014) investigated the occurrence of cattle and horses with vesicular lesions in the states of Paraíba and Rio Grande do Norte, and a virus associated with VSIV-3 was isolated.

This is the first study to characterize VSV circulation in the buffalo population in Northeastern Brazil, where infection is considered endemic (PANAFTOSA, 2010). Some aspects of virus maintenance are not fully understood, such as the role of reservoirs in endemic areas. The identification of seroreactive animals in this study demonstrates the circulation of VSIV-3 in buffaloes; however, reports of virus isolation in this species have not yet been described. Studies are needed to investigate the role of buffaloes in VS epidemiology.

\section{References}

ALLENDE, R.; GERMANO, P. M. L. Comparison of virus neutralisation and enzyme-linked immunosorbent assay for the identification of antibodies against vesicular stomatitis (Indiana 3) virus. Revue Scientifique et Technique, Rio de Janeiro, v. 12, n. 3, p. 849-855, 1993. DOI: 10.20506/rst.12.3.717

ALONSO FERNÁNDEZ, A.; SONDAHL, M. S. Antigenic and immunogenic characterization of various strains of the Indiana serotype of vesicular stomatitis isolated in Brazil. Boletín del Centro Panamericano de Fiebre Aftosa, Buenos Aires, n. 51, p. 27-30, 1985.

ANDRADE, C. M.; ROSAS, C. E.; AMORIM, L. L.; MOTA, J. P.; TEIXEIRA, E. N.; SANTOS, N. F. dos. Vesicular stomatitis in Brazil I - Isolation and identification of the Alagoas strain. Annals of Microbiology, Rio de Janeiro, v. 25, n. 1, p. 81-87, 1980.

ARRUDA, R. C. N.; SEGUNDO, J. M. F.; SOARES, B. A.; MARTINS, N. R. S.; BARÇANTE, T. A.; BARÇANTE, J. M. P. Investigação epidemiológica de Estomatite vesicular por achados clínicos em bovinos e equinos no Estado do Maranhão. Pesquisa Veterinária Brasileira, Seropédica, v. 35, n. 5, p. 391-395, 2015. DOI: $10.1590 / \mathrm{S} 0100-736 \mathrm{X} 2015000500001$

BEZERRA, C. S.; CARGNELUTTI , J. F.; SAUTHIER, J. T.; WEIBLEN, R.; FLORES, E. F.; ALVES, C. J.; CLEMENTINO, I. J.; SANTOS, C. S. A. B.; AZEVEDO,
S. S. Epidemiological situation of vesicular stomatitis virus infection in cattle in the state of Paraíba, semiarid region of Brazil. Preventive Veterinary Medicine, Gangtok, v. 160, p. 68-75, 2018. DOI: 10.1016/j. prevetmed.2018.09.027

CARGNELUTTI, J. F.; OLINDA, R. G.; MAIA, L. A.; AGUIAR, NETO, G. M.; MIRANDA, E. G.; SIMÕES, S. V. D.; LIMA, T. G.; DANTAS, A. F. M.; WEIBLEN, R.; FLORES, E. F.; RIET-CORREA, F. Outbreaks of vesicular stomatitis Alagoas virus in horses and cattle in northeastern Brazil. Journal of Veterinary Diagnostic Investigation, Gangtok, v. 26, n. 6, p. 788-794, 2014. DOI: $10.1177 / 1040638714553428$

CLEMENTINO, I. J.; LIMA, J. O.; COUTINHO, D. G.; ALBUQUERQUE, E. R. C.; GOMES, A. A. B.; AZEVEDO, S. S. First case report of vesicular stomatitis in the State of Paraíba. Brazil. Semina: Ciências Agrárias, Londrina, v. 35, n. 5, p. 2601-2606, 2014. DOI: 10.5433/1679-0359

FAUQUET, C. M.; MAYO, M. A.; MANILOFF, J.; DESSELBERGER, U.; BALL, L. A. Virus taxonomy: eighth report of the international committee on taxonomy of viruses. Cambridge: Academic Press, 2005. p. 509529 .

INTERNATIONAL COMMITTEE ON TAXONOMY OF VIRUSES - ICTV. Virus Taxonomy: 2018b Release. London: Microbiology Society, 2019. Available at: http:// www.ictvonline.org/vírusTaxonomy.asp. Accessed at: 4 jul. 2019.

KATZ, J. B.; ERNISSE, K. A.; LANDGRAF, J. G.; SCHMITT, B. J. Comparative performance of four serodiagnostic procedures for detecting bovine and equine vesicular stomatitis virus antibodies. Journal of Veterinary Diagnostic Investigation, London, v. 9, n. 3, p. 329-331, 1997. DOI: 10.1177/104063879700900321

KOTAIT, I. Estudo epidemiológico da estomatite vesicular no Vale do Paraíba, São Paulo. 1990. Dissertação (Mestrado em Saúde Pública) - Universidade de São Paulo, São Paulo.

LUNKES, V. L.; TONIN, A. A.; MACHADO, G.; CORBELLINI, L. G.; DIEHL, G. N.; SANTOS, L. C.; BEZERRA, C. S.; AZEVEDO, S. S.; PEQUENO, N. F.; SILVA, A. M.; WEIBLEN, R.; FLORES, E. F. Antibodies against vesicular stomatitis virus in horses from southern, midwestern and northeastern Brazilian States. Ciência Rural, Santa Maria, v. 46, n. 8, p. 1424-1429, 2016. DOI: $10.1590 / 0103-8478 \mathrm{cr} 20151135$

NOORDHUIZEN, J. P. T. M.; FRANKENA, K.; VAN DER HOOFD, C. M.; GRAAF, E. A. M. Application of quantitative methods in veterinary epidemiology. 
Wageningen Pers, Wageningen, v. 30, n. 1, p. 445, 1997. DOI: $10.3920 / 978-90-74134-89-7$

\section{PAN AMERICAN FOOT-AND-MOUTH DISEASE} CENTER - PANAFTOSA. Panaftosa reports. Washington: Global IRIS, 2010. Available at: http:// listserv.paho.org/. Accessed at: 10 july. 2019.

PAUSZEK, S. J.; BARRERA, J. C.; GOLDBERG, T.; ALLENDE, R.; RODRIGUEZ, L. L. Genetic and antigenic relationships of vesicular stomatitis viruses from South America. Archives of Virology, Heidelberg, v. 156, n. 11, p. 1961-1968, 2011. DOI: 10.1007/s00705011-1081-1

RODRIGUEZ, L. L. Emergence and re-emergence of vesicular stomatitis in the United States. Virus Research, New York, v. 85, n. 2, p. 211-219, 2002. DOI: 10.1016/ S0168-1702(02)00026-6
STEFANO, E. de; ARAÚJO, W. P.; PASSOS, E. C.; PITUCO, E. M. Pesquisa de anticorpos contra o vírus da Estomatite Vesicular em bovinos de corte criados na região de Araçatuba, Estado de São Paulo, Brasil em 2000. Brazilian Journal of Veterinary Research and Animal Science, São Paulo, v. 40, n. 1, p. 29-35, 2003. DOI: 10.1590/S1413-95962003000100003

STEFANO, E. de; PITUCO, E. M. Estomatite vesicular. In: MEGID, J.; RIBEIRO, M. G.; PAES, A. C. (Ed.). Doenças infecciosas em animais de produção e de companhia. Rio de Janeiro: Roca, 2016. p. 651-656.

WORLD ORGANISATION FOR ANIMAL HEALTH - OIE. Manual of diagnostic tests and vaccines for terrestrial animals 2017, 2015. Paris: OIE, 2015. Available at: http://www.oie.int/. Accessed at: 10 july. 2019. 